\title{
Detection of Chlorotoluene and Nitrotoluene Compounds by Recombinant Microbial Biosensors
}

\author{
Da Young Lee', Jae Ho Cho', Woon Ki Lim and Hae Ja Shin ${ }^{2}$ \\ ${ }^{1}$ Department of Molecular Biology, Pusan National University, Busan 609-735, Korea \\ ${ }^{2}$ Division of Energy and Bio-engineering, Dongseo University, Busan 617-716, Korea
}

Received October 16, 2013 /Revised January 16, 2014 /Accepted January 20, 2014

\begin{abstract}
Aromatic hydrocarbons are toxic environmental pollutants that are detrimental to the ecosystem and human health. Among them, chlorotoluene and nitrotoluene are toxic to hydrobios and irritate the skin, eyes, and respiratory organs of humans. We herein report the development of recombinant microbial biosensors for cheap and rapid monitoring of chlorotoluene and nitrotoluene compounds. Plasmids were constructed by inserting the $x y I R$ regulatory gene for BTEX (benzene, toluene, ethylbenzene, and xylene) degradation into upstream of $P O^{\prime}$ (the DmpR activator promoter Po with the deletion of its own upstream activating sequences) or $P u$ (the cognate promoter of XylR)::lac $Z$ (the $\beta$ -galactosidase gene) and transformed into Escherichia coli DH5a. In the presence of inducers, the biosensor cells immobilized in agarose developed a red color in 1-2 $\mathrm{h}$ due to the hydrolysis of chlorophenol red $\beta$-D-galactopyranoside $(\mathrm{CPRG})$, a substrate of $\beta$-galactosidase that was expressed by the inducers. Among BTEX, high responses were specifically observed with o-, m-, p-chlorotoluene $(0.1$ $\mu \mathrm{M}-100 \mathrm{mM})$ and o-, m-, p-nitrotoluene $(0.1 \mathrm{mM}-100 \mathrm{mM})$. Po' demonstrated higher responses than those with $\mathrm{Pu}$. The biosensors immobilized in agarose showed good stability after 21 days' storage at $4^{\circ} \mathrm{C}$, and responses in untreated wastewater spiked with chlorotoluene and nitrotoluene, suggesting they can be used to detect compounds in wastewater.
\end{abstract}

Key words : Chlorotoluene, nitrotoluene, recombinant microbial biosensor, XylR

\section{서 론}

모든 살아있는 세포들은 주변 환경에 민감하게 반응한다. 이 반응은 주변 환경에 존재하는 신호물질인 특정 ligands와 전사인자들(transcriptional factors) 사이의 인식과 결합에 의 해 시작된다. 결합된 복합체는 RNA 중합효소가 프로모터에 결합하게 하여 mRNA가 발현되도록 한다[18]. 이러한 전사인 자들은 세포 바이오센서에서 중요한 센서 요소로 활용되어 왔다[14].

XylR 단백질은 Pseudomonas에서 BTEX (benzene, toluene, ethylbenzene, 그리고 xylene) 화합물의 분해에 관여하는 전사 인자이다. BTEX 화합물이 있을 때 XylR 조절 단백질은 upper operon을 위해 $P u$ 를, XylS 유전자를 위해 $P_{S}$ 프로모터를 활성 화시켜 분해관련 유전자들을 발현시킨다. XylR은 $\sigma^{54}$ 의존성 $\mathrm{RNA}$ 중합효소에 활용하는 $\mathrm{NtrC}$ 패밀리에 속하는 조절 단백 질로 먼 자리에서도 프로모터에 작용한다[17]. XylR은 또한

\footnotetext{
*Corresponding author

Tel : +82-51-320-1791, Fax : +82-51-320-1781

E-mail : hjshin@gdsu.dongseo.ac.kr

This is an Open-Access article distributed under the terms of the Creative Commons Attribution Non-Commercial License (http://creativecommons.org/licenses/by-nc/3.0) which permits unrestricted non-commercial use, distribution, and reproduction in any medium, provided the original work is properly cited.
}

Pseudomonas sp. CF600에서 유래된 페놀분해 관련 DmpR 조 절단백질의 $\sigma^{54}$ 의존성 $P o$ 프로모터와도 상호 작용하여 활성 화시킨다[5]. $\mathrm{Pu}$ 와 $\mathrm{Po}$ 의 유전자배열은 다르지만, 이들은 공통 적으로 조절단백질이 결합하는 upstream activating sequences (UASs), $\sigma^{54}$ 의존성 RNA 중합효소가 결합하는 -12/-24 자리, 그리고 최적의 활성을 위한 integration host factor (IHF) 결합 자리를 가진다[19].

방향족 화합물에 의해 유도된 XylR은 올리고 형태로 전환 되고 UASs와 잘 결합하게 된다. 조절단백질과 결합된 UASs 와 먼 거리의 프로모터 자리가 DNA 루프를 형성하면서 가까 워진다고 보고되었다. 이 과정은 IHF가 UASs와 프로모터 사 이에 있는 IHF 결합자리에 결합하므로 이루어진다[2]. 방향족 화합물이 없을 시, 활성화 되지 않은 XylR이 전사의 시작을 위한 ATP 결합을 방해하거나 XylR 조절단백질의 ATPase 활 성을 방해한다고 알려져 있다[12]. 그러나 방향족 화합물 없이 도 조절단백질은 전사를 활성화시키기에 충분한 본질적인 ATPase 활성을 가지고 있으며 방향족 화합물의 유도에 의해 4 5배 더 활성화된다[11]. 대장균에 클로닝 된 XylR은 방향족 화합물의 유도 없이도 $P u$ 을 통해 전사한다는 보고가 있다[3]. 우리 또한 지난 연구에서 XylR 유전자와 고유의 $P u$ 프로모터 를 luciferase 표지 유전자와 함께 클로닝 하여 대장균에 형질 전환하였을 때 방향족 화합물의 유도 없이도 의미 있는 수준 의 바탕 활성을 나타내는 것을 관찰하였다[10]. 이 문제를 해결 
하기 위하여 $x y I R$ 유전자를 UASs을 제거한 돌연변이 $P O^{\prime}$ 또는 $P S$ 프로모터와 함께 luciferase 표지 유전자와 클로닝 하였으 며, $P o^{\prime}$ 에서 가장 적은 바탕 활성과 큰 반응을 얻었다[10].

본 연구에서는 현장에서 사용하기 쉬운 발색 근거 바이오센 서를 제작하기 위하여 $x y l R-P r-P u$ 와 $x y l R-P r-P O^{\prime}$ 을 $\beta$-galactosidase 표지 유전자와 클로닝 하여 비교 분석하였다.

\section{재료 및 방법}

\section{실험재료 및 시약}

아가로스는 USB corporation (Cleveland, OH, USA)에서, 배지와 agar는 Difco회사(Kansas, MO, USA)에서 구입하였다. $\mathrm{CPRG}$ 와 BTEX 화합물, 암피실린은 Sigma (St. Louis, MO, USA)에서 구입하였다. 플라스미드 DNA 정제 키트는 Qiagen (Hilden, Germany)에서, pGL3 basic vector와 pSV-Bgal vector은 Promega (Madison, WI, USA)에서, 각종 제한효소들, T4-DNA ligase는 Takara (Shiga, Japan)에서 구입하여 사용하 였다. 그 외 다른 시약들도 분석용도 수준의 시약을 구입하여 정제 없이 사용하였다.

\section{미생물과 배양조건}

플라스미드를 가진 대장균 DH5a은 $30 \mathrm{\mu g} / \mathrm{ml}$ 암피실린을 포함하는 TYS배지(1\% tryptone, $0.5 \%$ yeast extract, $0.5 \%$ $\mathrm{NaCl}$ 로 $37^{\circ} \mathrm{C}$ 에서 키웠다.

\section{$\mathrm{pLZXYIR}$ 제작}

BTEX 화합물 검출용 luciferase 바이오센서 플라스미드 pXRBTEX-Pu 또는 pXRBTEX-Po' [10]을 제한효소 KpnI 으로 처리하고 $x y I R P r P u$ 또는 $x y I R P r P O^{\prime}$ 가 포함된 약 $2.1 \mathrm{~kb}$ 을 분리 정제하여 같은 효소로 잘린 $\beta$-galactosidase 리포터 시스 템인 $6.6 \mathrm{~kb}$ 의 pGLacZ 벡타 플라스미드에 ligation하여 약 8.7 $\mathrm{kb}$ 의 pLZXylR 바이오센서 플라스미드를 제작하였다(Fig. 1).

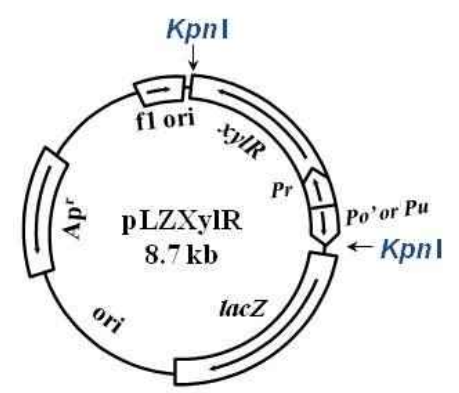

Fig. 1. Construction of plasmids. The $x y I R-P r-P u$ or $x y / R-P r-P o^{\prime}$ fragments were isolated from pXRBTEX-Pu or pXRBTEX$\mathrm{Po}^{\prime}$ and introduced upstream of $\beta$-galactosidase $\operatorname{lac} Z$ in the pGL- $\beta$-gal [10] to generate about $8.7 \mathrm{~kb}$ of the pLZXylR-Pu or pLZXylR-Po'. The arrows indicate the transcription or processing direction for genes.
pGLacZ 벡타 플라스미드는 다음과 같이 제작하였다. $1 \mu \mathrm{g}$ 의 pGL3 basic vector와 pSV-Bgal vector를 HindIII와 Sal I 을 처 리하여 $0.7 \%$ 아가로스겔 전기영동하여 pGL3 basic vector의 경우 $2.9 \mathrm{~kb}$ 를, $\mathrm{pSV}$ - $\beta$-gal vector의 경우 $3.7 \mathrm{~kb}$ 을 분리 정제하 여 ligation한 후 $\mathrm{CaCl}_{2}$ 방법으로 E. coli $\mathrm{DH} 5 a$ 에 형질 전환하 였다. 양끝말단이 동일한 제한효소 $K p n I$ 으로 cloning 되었으 므로 원하는 방향임을 확인하기 위해 RV3 primer와 Pu-R primer을 이용하여 PCR을 수행하거나 $\beta$-galactosidase의 발색반 응으로 올바르게 클로닝된 콜로니를 선별하였다. 플라스미드 는 Qiagen spin column 키트로 정제하였으며 클로닝, ligation, 형질전환은 표준 방법으로 수행하였다[13].

\section{세포고정, 세포수, 및 색발현시간}

pLZXylR biosensor plasmid을 갖는 재조합 E. coli DH5a를 최종농도 $50 \mathrm{\mu g} / \mathrm{ml}$ 되도록 $4 \mathrm{ml}$ 의 $30 \mu \mathrm{g} / \mathrm{ml}$ 암피실린이 들어 있는 TYS 배지에 접종하여 $37^{\circ} \mathrm{C}$ 에서 16 시간 진탕 배양하였 다. 약 30-50 $\mathrm{\mu l}$ 세포와 아가로스 $\left(0.2 \%, 40^{\circ} \mathrm{C}\right)$ 를 $1: 1$ 혼합하여 96-wells microplate에 $\beta$-galactosidase 기질인 CPRG (3 mM) 와 함께 고정하였다. 고정한 바이오센서 세포는 에탄올에 녹 인 방향족 화합물과 섞은 후 정해진 시간 동안 배양하였다. $\beta$-galactosidase 활성은 CPRG 분해에 의해 나타나는 붉은색 을 눈으로 검출하거나 microplate reader (Biorad, CA, USA) 로 $570 \mathrm{~nm}$ 에서 흡광도로 정 량하였다[4]. 최적 실험 조건을 결 정하기 위해 다양한 세포수(10-80 l) 및 색발현시간(1-6 hr)을 조사하였다.

\section{방향족 화합물의 처리 및 민감도 분석}

다양한 방향족 화합물들(benzene, toluene, ethylbenzene, o-, m-, p-xylene, o-, m-, p-chlorotoluene, o-, m-, p-methylbenzylalcohol, o-, m-, p-nitrotoluene)은 에탄올에 녹여 원하 는 농도로 희석하였다. $\beta$-galactosidase 활성 확인을 위해 에탄 올에 녹인 방향족 화합물들을 최종농도가 $1 \mathrm{mM}$ 이 되도록 아 가로스에 고정된 바이오센서 세포에 넣고 정해진 시간 동안 배양하였다. 눈으로 관찰 가능한 붉은색은 세포의 양에 따라 다소 차이가 있으나 1-2시간부터 나타나기 시작하였다. 또한 높은 반응성을 보이는 o-, m-, p-chlorotoluene과 o-, m-, p-nitrotoluene은 다양한 농도 범위 $(0.1 \mu \mathrm{M}-100 \mathrm{mM})$ 에서 반응을 관찰하였다.

Spiked된 폐수 분석 및 바이오센서 세포의 안정성 검사

현장 시료 분석을 위하여 아가로스에 고정된 바이오센서 세포를 포함하는 96-wells microplates을 현장에서 전처리 없 이 폐수에 노출한 후 눈으로 발색을 확인하거나 실험실로 가 져와 microplate reader로 흡광도를 읽어 정량하였다. 양성 데 이터를 얻기 위하여 폐수를 1:1로 희석한 후 반응성을 보이는 $1 \mathrm{mM}$ o-, m-, p-chlorotoluene와 o-, m-, p-nitrotoluene을 spike하여 고정된 바이오센서로 측정한 결과를 같은 화합물로 
spike한 완충용액 결과와 비교하였다. pLZXylR을 포함하는 아가로스 고정 바이오센서 세포의 안정성 검사를 위해 같은 날 같은 세포로 고정된 바이오센서 세포를 $0.5 \mathrm{mM}$ phosphate 완충용액( $\mathrm{pH}$ 7.0)으로 덮고 밀봉한 후 $4^{\circ} \mathrm{C}$ 에 보관하고 3,7 , 14,21 일에 $\beta$-galactosidase 활성을 관찰하였다.

\section{통계분석}

실험결과에 대한 유의성은 $p$ value $<0.05$ 를 유의성이 있는 값으로 인정하며, 실험결과는 means $\pm \mathrm{SD}$ 로 제시하였다.

\section{결과 및 고찰}

\section{플라스미드 pLZCapR 및 바이오센서시스템 제작}

조절 단백질 XylR은 고유의 프로모터인 $P u$ 와 UAS가 결손 된 $P O$ 를 활성화시키며 고유의 $P u$ 보다 $P O^{\prime}$ 와 융합되어 보다 더 높은 활성을 가진다고 보고되었다[10]. 본 연구에서는 기존 연구를 재확인하고 현장에서 간단하게 발색으로 화합물의 존 재여부를 확인하기 위하여 $\beta$-galactosidase 바이오센서 시스 템을 제작하였다(Fig. 1). Luciferase 플라스미드, pXRBTEX-

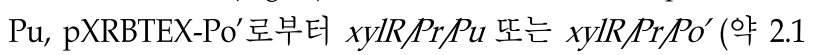
$\mathrm{kb})$ 를 분리 정제하여 $\beta$-galactosidase 리포터 시스템인 $\mathrm{pGLacZ}$ 벡타 플라스미드 $(6.6 \mathrm{~kb})$ 에 ligation하여 pLZXylR-Pu 또는 pLZXylR-Po' 바이오센서 플라스미드(약 $8.7 \mathrm{~kb})$ 을 제작하였 다(Fig. 1). 이 플라스미드들을 대장균 $\mathrm{DH} 5 \mathrm{a}$ 에 형질전환하고 아가로스와 $\beta$-galactosidase 기질인 CPRG와 함께 96-wells microplate에 고정하여 $\beta$-galactosidase 발색근거 바이오센서 시스템을 구축하고 그 반응 결과를 luciferase 시스템과 또는 두 프로모터간에 비교 분석하였다. 유도 화합물에 의한 모든 바이오센서 반응은 바탕실험에서 나타나는 $\beta$-galactosidase 반응을 보정하여 나타내었다.

\section{고정, 세포수, 발현 시간 최적화 실험}

재조합 바이오센서 세포는 변환기나 지지 매트릭스 고정에 의해 내성, 안정성, 오랜 기간 사용성 등이 증가 된다고 보고되 었다 $[1,6]$. 지난 연구에서 바이오센서 세포를 $0.2 \%$ 아가로스 에 고정하였을 때 2 주간 활성의 큰 변화 없이 안정하게 사용할 수 있음을 보고하였다[16]. 따라서 pLZXylR 플라스미드를 갖 는 바이오센서 세포를 아가로스와 혼합하여 96-wells microplate에 고정하였다. 현장에서 보다 간단하고 신속한 반응을 위하여 $\beta$-galactosidase 기질인 CPRG $(3 \mathrm{mM})$ 와 함께 고정하 여 현장 시료만 주입하여 발색으로 관찰하게 하였다. 분석물 질에 BTEX 유도 화합물이 존재할 경우, XylR 조절단백질이 활성화되고 조절단백질은 프로모터와 반응하여 downstream 에 위치한 $\beta$-galactosidase을 발현하며 기질 $\mathrm{CPRG}$ 는 분해되 어 노란색에서 붉은색으로 발색된다. 이를 현장에서 눈으로 확 인하거나 microplate reader에 의해 정량적으로 분석하였다. 최적의 실험조건을 구하기 위하여 세포수와 발현시간을 조
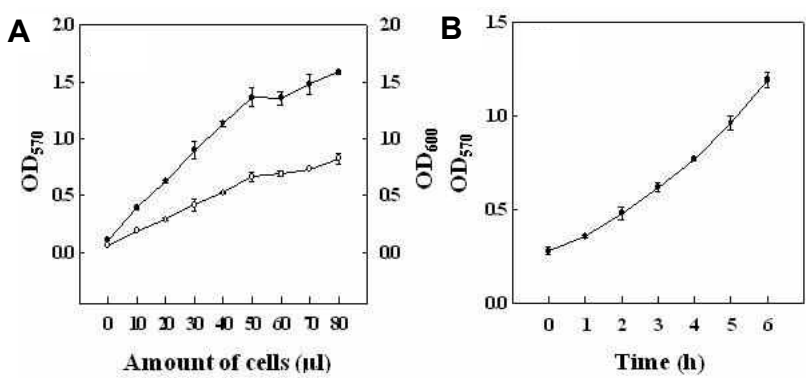

Fig. 2. Effects of cell density (A) and incubation time (B) on the activity of the biosensor. (A) Various amount of $E$. coli DH5a cells harboring plasmid pLZXylR-Po' were immobilized with $3 \mathrm{mM}$ CPRG in agarose, dispensed to 96 -well plates, exposed to $1 \mathrm{mM}$ p-chlorotoluene for $6 \mathrm{hr}$, and tested for B-galactosidase activity (closed circles) by absorbance at $\mathrm{OD}_{570} \mathrm{~nm}$. The cell density (open circles) was measured by absorbance at $\mathrm{OD}_{600} \mathrm{~nm}$. (B) $\beta$-galactosidase activities of biosensor cells containing pLZXylR-Po' were measured for the indicated time with $50 \mu \mathrm{l}$ cell density.

사하였다(Fig. 2A, 2B). 세포의 양이 증가할수록 $\beta$-galactosidase에 의한 분해가 증가하여 흡광도가 증가하였다(Fig. 2A). $\mathrm{Po}^{\prime}$ 와 $\mathrm{Pu}$ 모두 비슷한 결과를 보여주었으며 세포는 직선구간 에 있는 30-50 $\mu 1$ 를 최적 세포량으로 모든 실험에서 사용하였 다(Fig. 2A).

$\mathrm{CPRG}$ 와 함께 고정된 바이오센서 세포에 $1 \mathrm{mM}$ p-chlorotoluene을 넣고 CPRG가 분해되어 발색되는데 필요한 시간 을 측정하기 위해 시간별로 흡광도를 조사하였다(Fig. 2B). CPRG 분해로 인한 붉은색은 세포 양에 따라 다소 차이가 있 으나 대략 1-2시간부터 눈으로 관찰 되었으며 $\left(\mathrm{OD}_{570}=0.5\right)$ 보다 높은 흡광도( 1)을 얻기 위하여 모든 실험에서 약 5-6시간 정도 유도 발현시켰다. 발현되는 시간은 $P u$ 와 $P o^{\prime}$ 모두 비슷한 양상을 나타내었다.

\section{방향족 화합물의 처리 및 민감도 분석}

pLZXylR을 갖는 바이오센서 세포의 바이오 인지 능력을 BTEX 포함하여 15 개의 다양한 방향족 화합물 $(1 \mathrm{mM})$ 에 노출 하여 조사하였다(Fig. 3). 조사에 사용된 방향족 화합물들은 benezene, toluene, ethylbenzene, o-, $\mathrm{m}$-, p-xylene, $\mathrm{o-}, \mathrm{m}$-, $\mathrm{p}$ methylbenzylalcohol, o-, m-, p-chlorotoluene, o-, m-, p-nitrotoluene으로 구성되었다. $P o^{\prime}$ 와 $P u$ 모두 o-, m-, p-chlorotoluene, o-, m-, p-nitrotoluene에 반응성을 보여주었으며 $P O^{\prime}$ 가 o-, m-, p-chlorotoluene에서 $P u$ 와 거의 비슷하거나 약간 높은 반응을 보이나 o-, m-, p-nitrotoluene에서는 약 2 배 정도 더 높은 반응성을 보였다. 또한 $P o$ 는 p-xylene, o-, m-, p-methylbenzylalcohol에서도 반응을 나타내었다(Fig. 3). 이 는 지난 luciferase system [10]과 달리 $P u$ 와 $P o$ 가 $\beta$-galactosidase 시스템에서 특이하게도 o-, m-, p-chlorotoluene, o-, m-, 


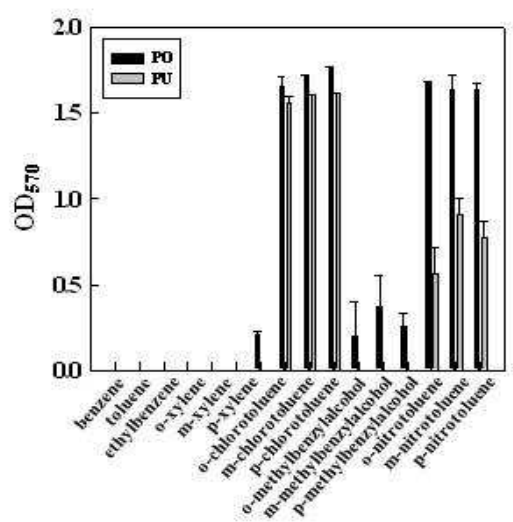

Fig. 3. Specificity of recombinant $E$. coli biosensor cells containing pLZXylR. Biosensor cells $(50 \mu l)$ containing pLZXylR were exposed to $1 \mathrm{mM}$ of the various aromatic compounds for $6 \mathrm{~h}$ and their $\beta$-galactosidase activities were detected as described in Fig. 2A.

p-nitrotoluene에 높은 반응성을 보인 반면 BTEX에는 거의 반 응을 보이지 않았다. 지난 연구에서 luciferase 시스템으로 o-, m-, p-xylene, o-chlorotoluene에서 비교적 높은 bioluminescence 활성을 나타내었으며 o-methylbenzylalcohol, p-chlorotoluene, toluene에서 약간의 반응성을, 그리고 나머지 화합물들에 아 주 약한 반응성을 보였다[10]. 이러한 차이점은 firefly luciferase 시스템과 $\beta$-galactosidase 시스템의 차이 또는 유전자 구 조체계에서 비롯될 것으로 사료된다. 즉, 대장균에서 진핵 반 딧불이 luciferase 유전자와 원핵 $\beta$-galactosidase 유전자의 다 른 발현 기작으로 인한 결과의 차이로 유추 되어 진다. Keane 그룹[7] 또한 진핵유전자 firefly luciferase가 대장균 안에서 불안정하게 발현된다고 보고하였다. 이러한 반응성의 차이점 은 다른 논문에서도 나타나는데 Willardson 그룹[20]은 pGL3 basic vector 대신 pGL2를 사용하였으며 p-methylbenzylalcohol 과 ethylbenzene이 $P u^{\prime}$ 에 의해 인지되지 않는다고 보고하였다 [20]. 종합적으로, 본 연구에서 제작한 pLZXylR 두 프로모터 시스템은 지난 연구에서 검출이 되지 않거나 약한 o-, m-, pchlorotoluene, o-, m-, p-nitrotoluene의 검출에 특이적으로 반 응함을 보여주었다(Fig. 3).

Fig. 4는 방향족 화합물 중에서 pLZXylR에 의해 높은 반응 성을 나타내는 o-, m-, p-chlorotoluene, o-, m-, p-nitrotoluene 의 다양한 농도 범위별 반응을 조사하였다. 바이오센서의 유 도에 필요한 농도들은 다양하게 나타났으며 대략적으로 o-, $\mathrm{m}$-, p-nitrotoluene은 약 $0.1 \mu \mathrm{M}$ 에서 $100 \mathrm{mM}$ 범위에서, 그리 고 o-, m-, p-chlorotoluene은 약 $0.1 \mathrm{mM}$ 에서 $100 \mathrm{mM}$ 범위에 서 $P o^{\prime}$ 프로모터가 $P u$ 에 비해 비슷하거나(o-, m-chlorotoluene 에서) 더 높은 반응(나머지 화합물들에서)을 보여준다(Fig. 4). Luciferase 시스템과 비교하면, luciferase 시스템에서는 $0.1 \mu \mathrm{M}$ 에서 $10 \mathrm{mM}$ 까지 반응성을 나타내고 $10 \mathrm{mM}$ 이상에서는 전혀 반응하지 않지만 본 $\beta$-galactosidase system에서는 상당히 높
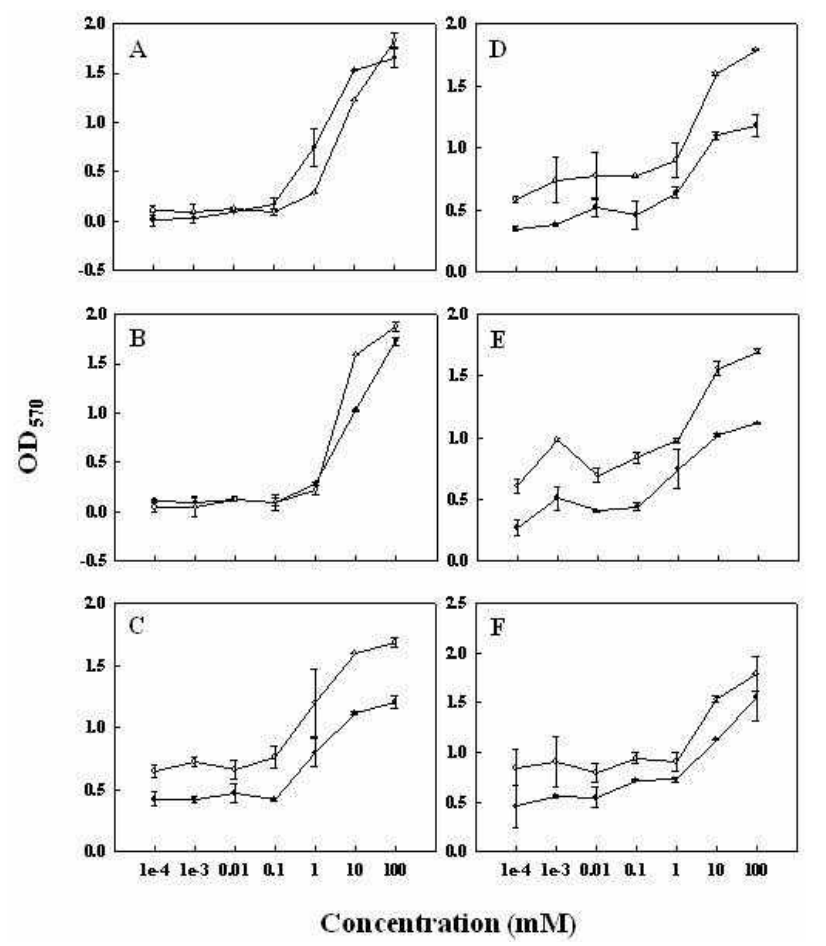

Fig. 4. Responses of the biosensor to various concentrations of chlorotoluene and nitrotoluene compounds. Biosensor cells containing pLZXylR-Po' (open circles) or pLZXylR$\mathrm{Pu}$ (closed circles) were treated with $0.1 \mu \mathrm{M}-100 \mathrm{mM}$ o(A), m- (B), p-chlorotoluene (C) and o- (D), m- (E), p-nitrotoluene $(F)$, and $\beta$-galactosidase activities were measured as described in Fig. 2A.

은 농도 $(100 \mathrm{mM})$ 에서도 반응성을 보인다. 이는 $\beta$-galactosidase 시스템에서는 손상되지 않는 세포를 이용하여 반응을 검출하므로 높은 농도의 페놀에서도 반응을 보이지만 luciferase 시스템에서는 세포를 깨어 반응을 검출하므로 높은 농도 에서는 효소가 비활성화되어 반응이 나타나지 않을 것으로 보인다. 반면, luciferase 시스템은 $\beta$-galactosidase system 보 다 검출 농도 범위에서 더 민감하게 반응한다고 보고되었다 [15]. 따라서 본 연구에서 제작한 $\beta$-galactosidase 시스템은 luciferase 시스템을 보완하며 비교적 높은 농도범위에서 o-, m-, p-chlorotoluene, o-, m-, p-nitrotoluene의 검출에 활용될 수 있다.

Spiked된 폐수 분석 및 바이오센서 세포의 안정성 검사 플라스미드 pLZXylR 함유 바이오센서 세포를 현장에서 활 용하기 위하여 환경 폐수 중에서도 이러한 o-, m-, p-chlorotoluene, o-, m-, p-nitrotoluene 화합물들 을 인지하는지 조사 하였다(Fig. 5). 폐수에 o-, m-, p-chlorotoluene, o-, m-, p-nitrotoluene을 spike한 후에 고정된 바이오센서 세포에 주입하여 발색을 확인하였다. 바이오센서 세포는 실험실 완충용액에서 와 같이 폐수에 spike된 화합물들을 인지하며 비슷하거나 약 


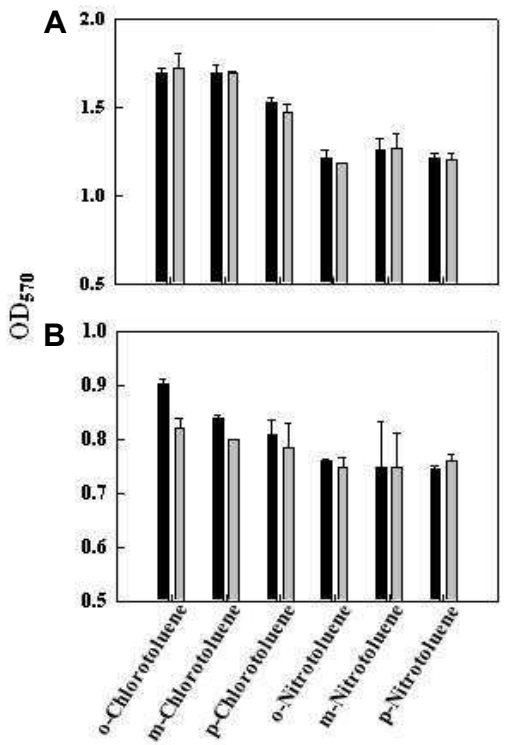

Fig. 5. Assessment of chlorotoluene and nitrotoluene compounds in buffer or wastewater. Biosensor cells were exposed to buffer (black bars) or wastewater (grey bars) spiked with $1 \mathrm{mM}$ of o-, m-, p-chlorotoluene, and o-, $\mathrm{m}-, \quad$ p-nitrotoluene. $\beta$-galactosidase activities were measured as described in Fig. 2A. A: Po', B: Pu.

간 낮은 반응을 나타내었다(Fig. 5). Po아 Pu에 비해 보다 높은 반응성을 나타내었으며, 특히 o-, p-chlorotoluene에서 가장 높 은 반응성을 보여 주었다. 이 결과는 pLZXylR을 갖는 바이오 센서가 현장폐수에서의 화합물 초기검출(존재유무)에 이용될 수 있음을 보여준다. 세포 바이오센서는 독성물질의 독성 및 생유용성 등 다양한 양상을 나타내는 것으로 알려져 있으며 [8], 정밀검출보다는 초기검출에 활용되어지며 따라서 보다 정 확한 페놀계 화합물의 농도결정에는 정밀한 기기분석이 필요 하다.

플라스미드 pLZXyIR을 갖는 바이오센서의 안정성 조사를 하였다(Fig. 6). 플라스미드 pLZXylR을 포함하는 아가로스 고 정 바이오센서 세포를 $0.5 \mathrm{mM}$ phosphate 완충용액(pH 7.0)으 로 덮고 밀봉한 후 $4^{\circ} \mathrm{C}$ 에 보관하고 21일간 $\beta$-galactosidase 활 성을 검사하였다. 두 프로모터는 비슷하게 21 일까지 큰 변화 없이 바이오센서 활성을 유지하는 것으로 관찰되었다. 이 안 정성은 기존 보고[16]와 유사하며 보다 장기간 바이오센서 세 포의 안정성은 표면 처리한 섬유상 망(fibrous matrices)에 고 정한 재조합 효모 세포에서 관찰되었다[9]. 또한 세포 반응은 통계적으로 받아들일 수 있는 표준편차 $( \pm 4.2 \% ; \mathrm{n}=6)$ 로 재현성 을 나타내었다.

결론적으로, 본 연구에서는 BTEX 분해 조절단백질 $x y l R$ 유 전자와 두 프로모터 $(P u$ 또는 $P o)$ 를 $\beta$-galactosidase 표지 유전 자와 결합하고 아가로스에 고정하여 방향족 화합물에 대한 반응성을 비교 분석하였다. 이 바이오센서는 BTEX 방향족 화 합물에 의해 $\beta$-galactosidase를 발현하고 기질인 chlorophenol

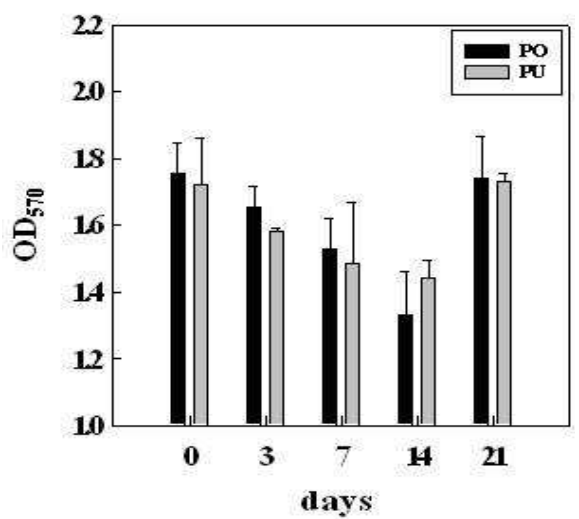

Fig. 6. Stability of the immobilized biosensor cells. Cells (50 $\mu \mathrm{l})$ were immobilized in $0.2 \%$ agarose and overlain with 100

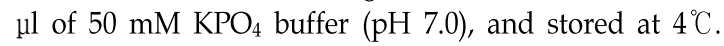
The cells were withdrawn after $3,7,14$, and 21 days, and incubated for $6 \mathrm{~h}$ in the presence of $1 \mathrm{~m} \mathrm{M}$ $\mathrm{p}$-chlorotoluene. $\beta$-galactosidase activities were measured as described in Fig. 2A.

red $\beta$-D-galactopyranoside (CPRG)를 분해하여 붉은색을 발 색함으로 검출한다. BTEX 방향족 화합물 중에서 $\mathrm{o}-, \mathrm{m}-, \mathrm{p}-$ chlorotoluene $(0.1 \mu \mathrm{M}-100 \mathrm{mM}), \mathrm{o}-, \mathrm{m}-$, p-nitrotoluene $(0.1$ $\mathrm{mM}-100 \mathrm{mM}$ ) 화합물들에 큰 반응을 보였으며 기존 luciferase 시스템과 같이 $P o^{\prime}$ 프로모터가 $P u$ 에 비해 더 높은 반응을 나타 내었으며, 기존 luciferase 시스템에 비해 높은 농도에서의 활 성을 보여 luciferase 시스템을 보완하여 활용될 수 있음을 제 시하였다. 아가로스에 고정된 바이오센서는 $4^{\circ} \mathrm{C}$ 에서 21 일간 보존 후에도 안정적인 반응을 보였으며 chlorotoluene과 nitrotoluene 화합물로 spike한 폐수 시료 중에서도 전처리 없이 활용될 수 있음을 보여주어 폐수 중 chlorotoluene과 nitrotoluene 화합물의 간단한 초기 검출에 활용될 수 있음을 보여 주었다.

\section{감사의 글}

본 연구는 교육과학기술부 한국연구재단(NRF)의 연구비 (2011-0007702)와 또한 일부 동서대학교 공학교육혁신센터 연 구비(2013)를 지원받아 수행하였으므로 이에 감사 드립니다.

\section{References}

1. Alvarez, G. S., Foglia, M. L., Copello, G. J., Desimone, M. F. and Diaz, L. E. 2009. Effect of various parameters on viability and growth of bacteria immobilized in sol-gel-derived silica matrices. Appl Microbiol Biotechnol 82, 639-646.

2. Bertoni, G., Fujita, N., Ishihama, A. and de Lorenzo, V. 1998. Active recruitment of $\sigma^{54}$ - RNA polymerase to the $P u$ promoter of Pseudomonas putida. role of IHF and aCTD. EMBO $J 17,5120-5128$. 
3. Delgado, A. and Ramos, J. 1994. Genetic evidence for activation of the positive transcriptional regulator XylR, a member of the NtrC family of regulators, by effector binding. J Biol Chem 269, 8059-8062.

4. Eustice, D. C., Feldman, P. A., Colberg-Poley, A. M., Buckery, R. M. and Neubaue, R. H. 1991. A sensitive method for the detection of beta-galactosidase transfected mammalian cells. Biotechniques 6, 739-743.

5. Fernández, S., Shingler, V. and de Lorenzo, V. 1994. Cross-regulation by XylR and DmpR activators of Pseudomonas putida suggests that transcriptional control of biodegradative operons evolves independently of catabolic genes. J Bacteriol 176, 5052-5058.

6. Jha, S. K., Kanungo, M., Nath, A. and D'Souza, S. F. 2009. Entrapment of live microbial cells in electropolymerized polyaniline and their use as urea biosensor. Biosens Bioelectron 24, 2637-2642.

7. Keane, A., Phoeniz, P., Ghoshal, S. and Lau, P. C. K. 2002. Exposing culprit organic pollutants. a review. J Microbiol Methods 49, 103-119.

8. Kelsey, J. W., Kottler, B. D. and Alexander, M. 1997. Selective chemical extractants to predict bioavailability of soil-aged organic chemicals. Environ Sci Technol 31, 214-217.

9. Kilonzo, P., Margaritis, A. and Bergougnou, M. A. 2011. Effects of surface treatment and process parameters on immobilization of recombinant yeast cells by adsorption to fibrous matrices. Bioresour Technol 102, 3662-3672.

10. Kim, M. N., Park, H. H., Lim, W. K. and Shin, H. J. 2005. Construction and comparison of Escherichia coli whole-cell biosensors capable of detecting aromatic compounds. $J$ Microbiol Methods 60, 235-245.

11. O'Neill, E., Wikstöm, P. and Shingler, V. 2001. An active role for a structured B-linker in effector control of the $\sigma^{54}$ - dependent regulator DmpR. EMBO J 20, 819-827.

12. Pérez-Martín, J. and de Lorenzo, V. 1996. Identification of the repressor subdomain within the signal reception module of the prokaryotic enhancer-binding protein XylR of Pseudomonas putida. J Biol Chem 271, 7899-7902.

13. Sambrook, J., Fritsch, E. F. and Manniatis, T. 2001. Molecular cloning: A Laboratory Manual, third ed. Cold Spring Harbor Laboratory, Cold Spring, New York.

14. Simpson, M. L., Sayler, G. S., Applegate, B. M., Ripp, S., Nivens, D. E., Paulus, M. J. and Jr. Jellison, G. E. 1988. Bioluminescence-reporter integrated circuits form novel whole-cell biosensors. Trends Biotechnol 16, 332-338.

15. Shin, H. J., Park, H. H. and Lim, W. K. 2005. Freeze-dried recombinant bacteria for on-site detection of phenolic compounds by color change. J Bacteriol 119, 36-43.

16. Shin, H. J. 2012. Agarose-gel-immobilized recombinant bacterial biosensors for simple and disposable on-site detection of phenolic compounds. Appl Microbiol Biotechnol 93, 18951904.

17. Shingler, V. 1996. Signal sensing by $a^{54}$-dependent regulators: depression as a control mechanism. Mol Microbiol 19, 409-416.

18. Stockley, P. G., Barton, A. J., Wild, C. M., Parsons, I. D., Miller, M. C., Holtham, C. A. M. and Baumber, S. 1998. Dissecting the molecular details of prokaryotic transcriptional control by surface Plasmon resonance. the methionine and arginine repressor peroteins. Biosens Bioeletron 13, 637-650.

19. Sze, C. C., Bernardo, L. M. D. and Shingler, V. 2002. Integration of global regulation of two aromatic-responsive $\sigma^{54}$-dependent systems: a common phenotype by different mechanisms. J Bacteriol 184, 760-770.

20. Willardson, B. M., Wilkins, J. F., Rand, T. A., Schupp, J. M., Hill, K. K., Keim, P. and Jackson, P. J. 1998. Development and testing of a bacterial biosensor for toluene-based environmental contaminants. Appl Environ Microbiol 64, 10061012. 
초록 : 재조합 미생물 바이오센서를 이용한 chlorotoluene과 nitrotoluene 화합물의 검출

이다영 $\cdot$ 조재호 ${ }^{1} \cdot$ 임운기 $\left.\right|^{1} \cdot$ 신혜자 ${ }^{2} \star$

( ${ }^{1}$ 부산대학교 분자생물학과, ${ }^{2}$ 동서대학교 에너지생명공학부)

방향족 화합물은 독성 환경오염물질로 생태계와 인간의 건강에 해로운 영향을 미친다. 그중 chlorotoluene과 nitrotoluene 화합물은 수생생물에 독성을 나타내며 인간의 피부, 눈, 호흡기를 자극한다. 본 연구에서는 폐수의 chlorotoluene과 nitrotoluene 화합물을 저렴하고 간단하게 검출하고자 재조합 미생물 바이오센서를 개발하였다. BTEX (benzene, toluene, ethylbenzene, xylene) 분해 조절 유전자 $x y I R$ 를 $P o^{\prime}$ (upstream activating sequences를 제거한 $\mathrm{DmpR}$ 조절단백질 promoter $P$ o) 또는 $\mathrm{Pu}$ (XylR 고유의 프로모터):: $1 a c Z$ 유전자(B-galactosidase 유전자)의 upstream에 연결한 플라스미드를 제작한 후, E. coli DH5a에 형질 전환하였다. 유도 화합물 존재 하에서, 아가로 스에 고정된 이 재조합 바이오센서 세포는 유도 화합물에 의해 $\beta$-galactosidase를 발현하고 기질인 chlorophenol red $\beta$-D-galactopyranoside (CPRG)를 분해하여 1 2시간에 붉은색을 나타내었다. BTEX 화합물 중, 특이적으로 o-, $\mathrm{m}$-, p-chlorotoluene $(0.1 \mu \mathrm{M}-100 \mathrm{mM})$ 그리고 o-, m-, p-nitrotoluene $(0.1 \mathrm{mM}-100 \mathrm{mM})$ 에서 높은 반응을 나타내었 으며 $P o$ 가 $P u$ 보다 높은 반응성을 보여주었다. 아가로스에 고정된 바이오센서는 $4^{\circ} \mathrm{C}$ 에서 21 일간 보존 후에도 활 성의 큰 변화 없이 안정하였으며, chlorotoluene과 nitrotoluene 화합물들로 spike된 전처리 하지 않은 폐수 시료 중에서도 좋은 반응을 보여 주어 폐수 중 chlorotoluene과 nitrotoluene 화합물의 간단한 초기 검출에 활용될 수 있음을 제시하였다. 